NBSIR 83-2699

\title{
Publications of the Mechanical Production Metrology Division in 1980-1982
}

U.S. DEPARTMENT OF COMMERCE

National Bureau of Standards

National Engineering Laboratory

Center for Manufacturing Engineering

Mechanical Production Metrology Division

Washington, DC 20234

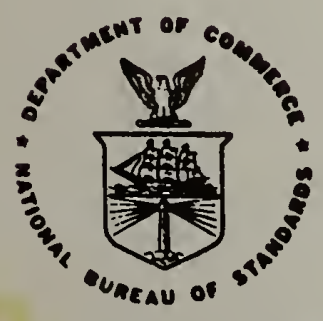

U.S. DEPARTMENT OF COMMERCE NATIONAL BUREAU OF STANDARDS 

NBSIR 83-2699

PUBLICATIONS OF THE MECHANICAL

PRODUCTION METROLOGY DIVISION IN 1980-1982

M. A. Cadoff

U.S. DEPARTMENT OF COMMERCE

National Bureau of Standards

National Engineering Laboratory

Center for Manufacturing Engineering

Mechanical Production Metrology Division

Washington, DC 20234

May 1983

U.S. DEPARTMENT OF COMMERCE, Malcolm Baldrige, Secrotary NATIONAL BUREAU OF STANDARDS. Emest Ambler, Director 



\section{INTRODUCT ION}

This bibliography lists the publications of the Mechanical Production Metrology Division (Center for Manufacturing Engineering, National Engineering Laboratory) for calendar years 1980-1982. Included in it are publications for which one or more authors were in the Mechanical Production Metrology Division during the 1980-1982 period. Also included are a few publications that were written in support of the Division's programs, even though none of the authors were members of the Division. All papers and reports published in 1980-1982 are included in this compilation, as well as those manuscripts that have been formally approved by NBS but not yet published.

As one of the two major laboratories of the National Bureau of Standards, the National Engineering Laboratory conducts research in engineering and the applied sciences and builds and maintains competences in the scientific disciplines required to carry out this research. The Laboratory provides the public and private sectors with improved technology and technical services that address national needs through the development of engineering measurements and data, test methods and proposed engineering standards, and new engineering practices. Within the National Engineering Laboratory, the Center for Manufacturing Engineering provides competence and develops technical data, findings, and standards in manufacturing eng ineering, mechanical metrology, automation and control technology, and industrial and mechanical engineering in support of the discrete parts manufacturing industries.

The Mechanical Production Metrology Division operates largely in the discipline of Applied Physics. It develops and maintains competence in engineering measurements and sensors, both static and dynamic, theoretical and experimental solid ncchanics, generalized (optical and mechanical) wave and inverse scattering, vibration analysis, acoustics research, and development of test methods, special tests, and calibrations of dynamic and static quantities including mass, force, acceleration, surface texture, acoustics, and optics. These competences are applied to problems in metrology, automated manufacturing, inspection technology to improve productivity, product quality, and occupational safety. The current organization of the Division is shown on the next page.

The publications in this bibliography are listed under the following headings:

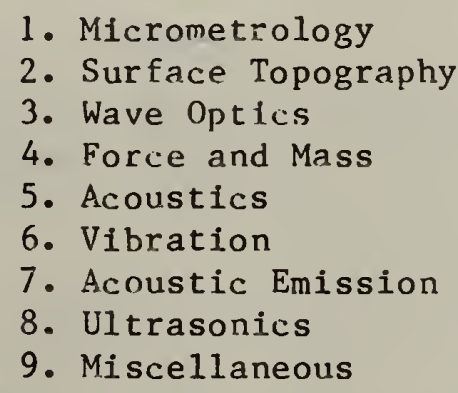

An author index is given at the end of this bibliography. 
MECHANICAL PRODUCTION METROLOGY DIVISION (737)

\author{
Daniel R. Flynn, Chief \\ Albert L. Hedrich, Senior Engineer \\ Marilyn A. Cadoff \\ Dorna D. Williams, Secretary
}

Micro and Optical Metrology

Group (737.02)

E. Clayton Teague, Leader

Sally A. Morris, Secretary

Optical Dimensional Metrology

Wilhelmina D. Jenkins 5

Thomas R. Lettieri

\section{Metrology of Microstructures}

Gary G. Hembree

John Unguris

\section{Surface Characterization}

David E. Gilsinn

Michael J. McLay 5

Fredric E. Scire

Theodore V. Vorburger

Russel1 D. Young ${ }^{1}$

Wave Optics

A. George Lieberman

Egon Marx

Particle Standards

Arie W. Hartman

George W. Mulholland 2

${ }^{1}$ Guest Worker

2 Detailed (part-time) from Center for Fire Research

${ }^{3}$ Consultant

${ }^{4}$ Detailed from Office of Nondestructive Evaluation

${ }^{5}$ Student

${ }^{6}$ Detailed to Industrial Systems Division
Force and Acoustics Group (737.04)

Donald G. Eitzen, Leader

Kathy D. Kilmer, Secretary

Martin Greenspan ${ }^{3}$

Deborah A. Neal

Acoustic Emission

Transducers

Franklin R. Breckenridge

Thomas M. Proctor

Acoustic Emission Methods

Michael F. Barsky 5

Nelson H. Hsu

Martin P. Jones 5

U1trasonic Transducers

Steven E. Fick

Carl E. Tschiegg ${ }^{1}$

Ultrasonic Applications

Gerald V. Blessing

Carl W. Thompson 4,5
Daniel R. Flynn, Leader

Peggy A. Grimes, Secretary

Force and Mass

Richard A. Mitcheli

Clare W. Amoruso

Linwood Jenkins

Jerry G. Keller

Robert W. Peterson

Paul E. Pontius 1

Ricky L. Seifarth

Douglas R. Tatel

Acoustics

Victor Nedzelnitsky

David J. Brenner 6

Edwin D. Burnett

Edith L. R. Corliss

\section{Vibration}

M. Roman Serbyn Charles Federman

Mal Huong Nguyen 5

Beverly F. Payne

Mechanical Testing

Donald C. Robinson

James A. Huckeba
Linda L. Martinez 


\section{Micrometrology}

1.1 Hartman, A.W.; Nyyssonen, D.; Swing, R.E. SEM/interferometer system, chapter 5 in Accurate linewidth measurements on integrated-circuit photomasks. J. M. Jerke, ed. Nat. Bur. Stand. (U.S.) Spec. Pub. 400-43; 1980 February. $51-77$.

1.2 Hembree, G.G.; Jensen, S.W.; Marchiando, J.F. Monte Carlo simulation of submicrometer linewidth measurements in the scanning electron microscope. Proceedings of the microbeam analysis society. R. H. Geiss, ed. San Francisco, California: San Francisco Press; 1981. 123-126.

1.3 Hembree, G.; Jensen, S.; Marchiando, J. Sub-micrometer linewidth measurements by electron microscopy. G. Bailey, ed. Proceedings of the 38 th annual electron microscopy society of America. Baton Rouge, Louisiana: Claitor's Publishing Div•; 1980. 312-313.

1.4 Jensen, S. Planar micrometrology in the SEM. Proceedings of the Microbeam Analysis Society. San Francisco, California: San Francisco Press; 1980. 77-84.

1.5 Jensen, S.; Hembree, G.; Marchiando, J.; Swyt, D. Quantitative sub-micrometer linewidth determination using electron microscopy. "Semiconductor microlithography VI." Proc. Soc. Photo-Opt. Instrum. Engrs. (SPIE) 275: 101-108; 1981.

1.6 Jensen, S.; Swyt, D. Sub-micrometer length metrology: problems, techniques and solutions. Scanning electron microscopy 1980/I. AMF 0-Hare, Chicago, Illinois: SEM, Inc.; 1980. 393-406.

1.7 Jerke, J.M.; Hartman, A.W.; Nyyssonen, D.; Swing, R.E.; Young, R.D.; Keery, W.J. Comparison of linewidth measurements on an SEM/interferometer system and an optical linewidth-measuring microscope, appendix $D$ in Accurate linewidth measurements on integrated-circuit photomasks. J. M. Jerke, ed. Nat. Bur. Stand. (U.S.) Spec. Publ. 400-43; 1980 February. 146-154.

1.8 Lettieri, T.R.; Jenkins, W.D.; Swyt, D.A. Sizing of individual optically levitated evaporating droplets by measurement of resonances in the polarization ratio. Appl. Opt. 20(16): 2799-2805; 1981 .

1.9 Lettieri, T.R.; Jenkins, W.D.; Swyt, D.A. A laser-based resonant scattering system for size measurement of individual droplets and microspheres. Optoelectronics in technology: proceedings of the laser 81 opto-elektronik conference. Berlin, Germany: Springer-Verlag; 1982. 171-175.

1.10 Marx, E.; Mulholland, G.W. Size and refractive index determintion of single polystyrene spheres. J. Aerosol Res. \& Tech. (to be published)

1.11 Rosberry, F.W.; Swyt, D.A. Conventional optical microscopes, chapter 7 in Accurate linewidth measurements on integrated-circuit photomasks. J. M. Jerke, ed. Nat. Bur. Stand. (U.S.) Spec. Pub. 400-43; 1980 February. 95-104. 
1.12 Swyt, D. A. A look at techniques for the dimensional calibration of standard microscopic particles. Nat. Bur. Stand. (U.S.) Spec. Pub. SP-260. (to be published)

1.13 Swyt, D.A.; Jensen, S.W. An electron-microscope-based system for accurate microdimensional measurements. Precision Engng. 3(1): 11-15; 1981.

1.14 Swyt, D.; Jensen, S. The measurement of small dimensions of products and by-products. Proc. Soc. Photo-0pt. Instrum. Engrs. (SPIE) 220: 28-35; 1980.

1.15 Swyt, D.A.; Lettieri, T.R.; Hartman, A.W.; Jensen, S.W. Techniques for calibration of microscopic particle size standards. Proceedings of the fine particle society fall meeting; 1980 September; Washington, D.C. (in press)

1.16 Swyt, D.A.; Rosberry, F.W. A comparison of some optical microscope measurements of photomask linewidths, appendix C in Accurate linewidth measurements on integrated-circuit photomasks. J. M. Jerke, ed. Nat. Bur. Stand. (U.S.) Spec. Pub. 400-43; 1980 February. 140-145.

\section{Surface Topography}

2.1 Church, E.L.; Howells, M.R.; Vorburger, T.V. Spectral analysis of the finish of diamond-turned mirror surfaces. Proc. Soc. Photo-Opt. Instrum. Engrs. (SPIE) (Reflecting optics for synchrotron radiation) 315: 200-217; 1981.

2.2 Feldman, A.; Vorburger, T. Comparison of optical and mechanical methods of thickness measurement. Soc. Photo-Opt. Engrs. (SPIE) (Integrated circuit metrology) 342: 92-99; 1982.

2.3 Tanimura, Y.; Teague, E.C.; Scire, F.E.; Young, R.D.; Vorburger, T.V. Graphical signature for manufactured surfaces. Bull. of NRLM 30(1)(No. 101): 37-42; 1981 January.

2.4 Tanimura, Y.; Teague, E.C.; Scire, F.E.; Young, R.D.; Vorburger, T.V. Graphical signatures for manufactured surfaces. J. Lubrication Tech. 104: 533-537; 1982 October.

2.5 Teague, E.C.; Scire, F.E.; Vahey, D.; Mueller, E. Developing measurement standards for edge characterization of intraocular lenses. The impact of standards and technology of medical devices. (to be published by ASTM)

2.6 Teague, E.C.; Vorburger, T.V.; Scire, F.E.; Jensen, S.W.; Baker, S.M.; Trahan, C.; Gloss, B.B. Evaluation of methods for characterizing surface topography of high Reynolds number wind-tunnel models, in Proceedings of the AIAA 12th aerodynamic testing conference; 1982 March 21-24; Williamsburg, Virginia. American Institute of Aeronautics and Astronautics Conference Publication 822 ; $1982.246-251$. 
2.7 Teague, E.; Vorburger, T.; Scire, F.; Gilsinn, D.; McLay, M.;

Trahan, C. Optical measurement of surface roughness. Technical activities 1982--Office of Nondestructive Evaluation. H.T. Yolken, ed. Nat. Bur. Stand. (U.S.) NBSIR 82-2617; 1982 December. 90-95.

2.8 Teague, E.C.; Vorburger, T.V.; Birnbaum, G. Optical nondestructive evaluation. Encyclo. Matls. Sci. and Engng. (to be published)

2.9 Teague, E.C.; Scire, F.E.; Vorburger, T.V. Sinusoidal profile precision roughness specimens. Wear 83: 61-73; 1982 .

2.10 Teague, E.C.; Scire, F.E.; Baker, S.M•; Jensen, S.W. Three-dimensional stylus profilometry. Wear $83: 1-12 ; 1982$.

2.11 Teague, E.C.; Vorburger, T.V.; Maystre, D. Light scattering from manufactured surfaces. Annals of the CIRP 30: 563-569; 1981.

2.12 Trahan, C.Y.; Jensen, S.W. BASIC utility graphics software for the Hewlett-Packard 9845B desk-top computer. Nat. Bur. Stand. (U.S.) NBSIR 82-2566; 1982 October. 151 p.

2.13 Vorburger, T.V.; Ludema, K.C. Ellipsometry of rough surfaces. App1. Opt. 19: 561-573; 1980 .

2.14 Vorburger, T.V.; Scire, F.E.; Teague, E.C. Hydrodynamic drag versus roughness for rotating disks. Wear 83: 339-349; 1982.

2.15 Vorburger, T.V.; Teague, E.C. Optical techniques for on-line measurement of surface topography. Precision Engng. 3: 61-83; 1981 .

2.16 Vorburger, T.V.; Scire, F.E.; Teague, E.C. Surface roughness measurements of circular disks and their correlation with hydrodynamic drag. Nat. Bur. Stand. (U.S.) Tech. Note 1151; 1982 January. 63 p.

2.17 Young, R.D.; Vorburger, T.V.; Teague, E.C. In-process and on-1ine measurement of surface finish. Annals of the CIRP 29:435-440; 1980 August.

\section{Wave Optics}

3.1 Lieberman, A.G. An electromagnetic formulation for treating optical reflections from graded-material surfaces. Nat. Bur. Stand. (U.S.) Tech. Note $1171 ; 1982$ December. 36 p.

3.2 Lieberman, A.G. Dimensional metrological errors resulting from the hard boundary assumption. Bu11. Am. Phys. Soc. 26(4): 619; 1981 April.

3.3 Lieberman, A.G. Field constraints on discontinuous solutions of Maxwell equations. AIP conference proceedings, optics in four dimensions; 1980; Ensenada, Mexico. New York, New York: American Institute of Physics; 1981. 652. 
3. 4 Lieberman, A.G. Jump conditions across a propagating electromagnetic

fleld discontinuity. Bul1. Am. Phys. Soc. 25(4): 565; 1980 April.

3.5 Lieberman, A.G. Metrological consequences of the hard optical boundary assumption for a metal surface. Nat. Bur. Stand. (U.S.) Tech. Note. (to be published)

3.6 Lieberman, A.G. Reflection coefficients for depth-dependent materials; theory and metrology. J. Opt. Soc. Am. 71(12): 1575; 1981 December.

3.7 Lieberman, A.G. Time-resolved optical reflections from the surface of dispersive media. J. Opt. Soc. Am. 72(12): 1812; 1982 December.

3.8 Lieberman, A.G.; Marchiando, J. Transient reflection of transverse electric plane waves by flat, dispersive surfaces. Bul1 Am. Phys. Soc. 27(4): 559; 1982 April.

3.9 Marx. E.; Maystre, D. Dyadic Green functions for the time-dependent wave equation. J. Math. Phys. 23(6): 1047-1056; 1982 June.

3.10 Marx, E. Integral equation for scattering by a dielectric. IEEE Trans. Antennas \& Propagation. (to be published)

3.11 Marx, E. Integral equations for transient electromagnetic fields. Nat. Bur. Stand. (U.S.) Tech. Note 1157; 1982 February. 68 p.

3.12 Marx, E. Single integral equation for wave scattering. J. Math. Phys. 23(6): 1057-1065; 1982 June.

\section{Force and Mass}

4.1 Fainberg, A.; Gordon, D.; Dermendjlev, E.; Terrey, D.; Mitche11, R.A. A portable load-cell based system for welghing UF 6 cylinders. Proceedings of the International Atomic Energy Agency Symposium (IAEA); 1982 November;

Vienna, Austria.

4.2 Hudson, C. A study of the economic aspects of NBS load cell calibration services. 1980 May 1. 32 p. (Unpublished report)

4.3 Mitchel1, R.A.; Pontius, P.E. Force sensor-machine interaction.

Proceedings of the 27 th international instrumentation symposium (ISA);

Indianapolis, Indiana. Instrumentation in the Aerospace Industry 27: 225-232; 1981.

4. 4 Pontius, P.E.; Mitchell, R.A. Inherent problems in force measurement. Exper. Mech., J. Soc. Exper. Stress Anal. 22(3): 81-88; 1982 March.

4.5 Suda, S.; Pontius, P.; Schoonover, R. Improved mass measurement accuracy using the PNB load cell scale. J. Inst. Nucl. Matls. Mgmt. 10: 266-271; 1981 . 
4.6 Varner, R.N.; Raybold, R.C. National Bureau of Standards mass calibration computer software. Nat. Bur. Stand. (U.S.) Tech. Note 1127; 1980 July. 158 p.

\section{Acoustics}

5.1 Barte1, T.W. Effect of absorber geometry on apparent absorption coefficients as measured in a reverberation chamber. J. Acoust. Soc. Am. 69(4): $1065 ; 1981$.

5.2 Bartel, T.W. Studies on the variation of absorption coefficient with absorber geometry. J. Acoust. Soc. Am. 67(Supp1. 1): S83; 1980. (abstract only)

5.3 Bartel, T.W.; Yaniv, S.L.; Flynn, D.R. Use of "corner microphones" for sound power measurements in a reverberation chamber. J.Acoust. Soc. Am. (to be published)

5.4 Burnett, E.D.; Beck, L.B. Comprehensive measurements of the characteristics of compression hearing aids. J. Acoust. Soc. Am. 68 (Supp1. 1): S58; $1980 \mathrm{Fall}$. (abstract only).

5.5 Burnett, E.D. National Bureau of Standards hearing aid test procedures, chapter III in Handbook of hearing aid measurement-1980. L. B. Beck, ed. Veterans Admin. (U.S.) Report IB 11-69; 1980 March. 8-212.

5.6 Burnett, E.D. National Bureau of Standards hearing aid test procedures, chapter III in Handbook of hearing aid measurement-1981. M. T. Howard, ed. Veterans Admin. (U.S.) Report IB 11-72; 1981 March. 8-176.

5.7 Burnett, E.D.; Tarica, M. National Bureau of Standards hearing aid test procedures and test data, Chapter III in Handbook of hearing aid measurement1982. M.T. Howard, ed. Veterans Admin. (U.S.) Report IB 11-74; 1982 March. 8-221.

5.8 Burnett, E.D.; Corliss, E.L.R.; Nedzelnitsky, V. Research problems in coupler and in situ measurements on hearing aids, in The Vanderbilt hearing-aid report state of the art-research needs. G. A. Studebaker; F. H. Bess, eds. Upper Darby, Pennsylvania: Monographs in Contemporary Audiology; 1982 December. 67-73.

5.9 Corliss, E.L.R. Large-scale check on the consistency of coupler threshold standards. J. Acoust. Soc. Am. 67 (Suppl. 1): S91; 1980 Spring. (abstract only)

5.10 Corliss, E.L.R. Accessible calibration technique for mechanical impedance measurements. J. Acoust. Soc. Am. 70 (Supp1. 1): S11; 1981 Fall. (abstract only)

5.11 Donavan, P.R.; Flynn, D.R.; Yaniv, S.L. Highway noise criteria study: outdoor/indoor noise isolation. Nat. Bur. Stand. (U.S.) Tech. Note 1113-2; 1980 August. $180 \mathrm{p}$. 
5.12 Flynn, D.R.; Voorhees, C.R.; Yaniv, S.L. Highway noise criteria study: traffic noise data base. Nat. Bur. Stand. (U.S.) Tech. Note 1113-1; 1980 April. $381 \mathrm{p}$.

5.13 Flynn, D.R.; Yaniv, S.L. Highway noise criteria study: relations among frequency rating procedures. Nat. Bur. Stand. (U.S.) Tech. Note 1113-3. (in press)

5.14 Greenspan, M. Acoustical research in the physical sciences: properties of gases, liquids, and solids. J. Acoust. Soc. Am. 68: 29-35; 1980.

5.15 Lynch, T.J., III; Nedzelnitsky, V.; Peake, W.T. Input impedance of the cochlea in cat. J. Acoust. Soc. Am. 72(1): 108-130; 1982 July.

5.16 Nedzelnitsky, V.; Tarica, M. Aerodynamic impact sound from colliding spheres for calibration of microphone systems. J. Acoust. Soc. Am. 68 (Suppl. 1): S20-1; $1980 \mathrm{Fa11}$. (abstract only)

5.17 Nedzelnitsky, V.; Burnett, E.D.; Penzes, W.B. Calibration of laboratory condenser microphones. Proceedings of the 10th transducer workshop. W.D. Anderson; C.E. Thomas, eds. 1980 March; White Sands Missile Range, New Mexico. 27-48.

5.18 Nedzelnitsky, V. Characterization and calibration of microphone systems for measurement of impulselike sounds. J. Acoust. Soc. Am. 72 (Supp1. 1); S53; $1982 \mathrm{Fall}$. (abstract only)

5.19 Nedzelnitsky, V. Sound pressures in the basal turn of the cat cochlea. J. Acoust. Soc. Am. 68(6): 1676-1689; 1980 December.

5.20 Nedzelnitsky, V. Traceability of acoustical instrument calibration to the National Bureau of Standards. Proceedings of INTER-NOISE 80; 1980 December 8-10; Miami, Florida. Poughkeepsie, New York: Nolse Control Foundation; 1980. 1043-1046.

5.21 Yaniv, S.L.; Bauer, J.W.; F1ynn, D.R.; Danner, W.F. Effects of time-varying noise on annoyance: a review. Nat. Bur. Stand. (U.S.) NBSIR $81-2377$; 1981 October. 56 p.

5.22 Yaniv, S.L.; Flynn, D.R. Highway noise criteria study: technical summary. Nat. Bur. Stand. (U.S.) NBSIR 82-2610; 1982 October. 38 p.

5.23 Yaniv, S.L.; Flynn, D.R.; Corley, D.M.; Cadoff, M.A. Procedure for assessing impact on public health and welfare due to noise emitted by household and consumer products. Nat. Bur. Stand. (U.S.) NBSIR 80-2137 (Restricted); 1980 September. 143 p.

5.24 Yaniv, S.L.; Flynn, D.R. Proposed standard methods for measuring and rating steady-state room noise. Proceedings of INTER-NOISE 80; 1980 December 8-10; Miami, Florida. Poughkeepsie, New York: Noise Control Foundation; 1980. 1163-1168. 


\section{Vibration}

6.1 Payne, B.F. Absolute calibration of back-to-back accelerometers. 27 th international instrumentation symposium; 1981 May; Indianapolis, Indiana; 1981. 483-488

6.2 Payne, B.F.; Edelman, S.; Mordfin, L. Enhanced reliability and reproducibility of machine vibration measurements. Proceedings of the 6 th machinery dynamics seminar; 1980 August; National Research Council of Canada.

6. 3 Payne, B.F. The use of back-to-back accelerometers as precision vibration standards. Proceedings of the lst international modal analysis conference; 8-10 November 1982; Orlando, Florida. Schenectady, New York: Union College; 1982.

6. 4 Serbyn, M.R.; Penzes, W.B. A real-time active vibration controller. 27 th international instrumentation symposium; 1981 May; Indianapolis, Indiana; 1981. 489-494.

5.5 Serbyn, M.R.; Penzes, W.B. A real-time active vibration controller. ISA Trans. 21(3): 55-59; 1982 .

6.6 Serbyn, M.R. Absolute measurement of angular vibration. Proceedings of the 1lth transducer workshop; 1981 June; Seattle, Washington. 260-270.

6.7 Serbyn, M.R.; Payne, B.F. Automation of the fringe-disappearance method for calibrating vibration pickups. J. Acoust. Soc. Am. 68 (Supp1.1): S75; $1980 \mathrm{Fall}$. (abstract only)

6. 8 Serbyn, M.R. Interferometric phase calibration of vibration pickups. Proceedings of the lst international modal analysis conference; $8-10$ November 1982 ; Orlando, Florida. Schenectady, New York: Union College; 1982.

\section{Acoustic Emission}

7.1 Baum, M. The sounds of failure. Developments in acoustic emission research. Nat. Bur. Stand. (U.S.) Dimensions 64(4): 12-18; 1980 May-June.

7.2 Berger, H.; Birnbaum, G.; Eitzen, D.G. NDT measurements traceable to NBS, paper $P$ in Proceedings of the tenth world conference on non-destructive testing--plenary papers; 23-27 August 1982; Moscow, U.S.S.R. 58-65.

7.3 Birnbaum, G.; Eitzen, D.G. Future directions of ultrasonic NDE standards in the U.S., paper no. 7-5 in Proceedings of the tenth world conference on non-destructive testing--contributed papers; 26 August 1982; Moscow, U.S.S.R. 267-272.

7.4 Birnbaum, G.; Berger, H.; Eitzen, D.G. Traceable NDE standards. Proceedings of the 13th symposium on nondestructive evaluation; 1981 April 2123; San Antonio, Texas. 
7.5 Breckenridge, F.R. Acoustic emission transducer calibration by means of the seismic surface pulse. J. Acoust. Emission 1(2): 87-94; 1982.

7.6 Breckenridge, F.R.; Watanabe, T.; Hatano, H. Calibration of acoustic emission transducers: comparison of two methods. Proceedings of the 6 th international acoustic emission symposium; 31 October-3 November 1982; Susono, Japan. 448-458.

7.7 Breckenridge, F.R.; Greenspan, M. Surface-wave displacement: absolute measurements using a capacitive transducer. J. Acoust. Soc. Am. 69(4): 1177-1185; 1981 April.

7.8 Bruchley, W.J.; Fick, S.E.; Green, R.E. Analysis of acoustic emission during plastic deformation of micro-tensile specimens by optical probing. Proceedings of the second international symposium on ultrasonic materials characterization; 1980 June; Gaithersburg, Maryland.

7.9 Eitzen, D.G.; Quinn, J. R. Electric Power Research Institute/National Bureau of Standards joint program on acoustic emission. RP 608-3, section 35 in Nondestructive evaluation program progress in 1981. Coe Corp., eds. NP-2088-SR. Palo Alto, California: Electric Power Research Institute; 1981 December. 35-1 - 35-18.

7.10 Eitzen, D.G. Electric Power Research Institute/NBS joint program on acoustic emission. Nondestructive evaluation program: progress in 1981. G. Dau, et al., eds. EPRI Report No. NP-2088-SR. Palo Alto, California: Electric Power Research Institute; 1982 January.

7.11 Eitzen, D.; Breckenridge, F.; Hsu, N.; Proctor, T.; Clough, R.; Simmons, J.; Stockton, C.; Wadley, H. EPRI/NBS joint program on acoustic emission. Technical activities 1982--Office of Nondestructive Evaluation. H. T. Yolken, ed. Nat. Bur. Stand. (U.S.) NBSIR 82-2617; 1982 December. 4-19.

7.12 Eitzen, D.G.; Breckenridge, F.R.; Clough, R.B.; Fuller, E.R.; Hsu, N.N.; Simmons, J.A. Fundamental developments for quantitative acoustic emission measurements. EPRI NP-2089; Project 608-1. Palo Alto, California: Electric Power Research Institute; 1981 October. 242 p.

7.13 Eitzen, D.G.; et al. Fundamental developments in acoustic emission measurements: the NBS program. Proceedings of quantitative NDE in the nuclear industry; 1982 May.

7.14 Eitzen, D.; Breckenridge, F.; Clough, R.; Hsu, N.; Proctor, T.; Simmons, J. NBS developments in quantitative acoustic emission measurements.

Proceedings of the DARPA/AF review of quantitative NDE; 1981 August; Boulder, Colorado.

7.15 Eitzen, D.; Breckenridge, F.; Clough, R.; Hsu, N.; Proctor, T.; Simmons, J. NBS developments in quantitative acoustic emission measurements. Review of progress in quantitative nondestructive evaluation, Vol. 1. D.0. Thompson; D.E. Chimenti, eds. New York, New York: Plenum Press; 1982. 433-442.

7.16 Eitzen, D.G.; Breckenridge, F.R.; Clough, R.B.; Fuller, E.R.; Hsu, N.N.; Simmons, J.A. Summary of fundamental developments for quantitative acoustic emission measurements. EPRI NP-1877; Research Project 608-1. Palo Alto, California: Electric Power Research Institute; 1981 June. 86 p. 
7.17 Greenspan, M.; Tschiegg, C.E. Radiation-induced acoustic cavitation; threshold vs. temperature for some liquids. J. Acoust. Soc. Am. 72(4): 1327-1331; 1982 October.

7.18 Greenspan, M.; Eitzen, D.G. Ultrasonic research: summary report and literature guide to the National Bureau of Standards/Office of Naval Research program. Nat. Bur. Stand. (U.S.) NBSIR 82-2529; 1982 June. $1 \mathrm{lp}$.

7.19 Hsu, N.N.; Eitzen, D.G. AE signal analysis - laboratory experiments examining the physical processes of acoustic emission. Proceedings of the fifth international acoustic emission symposium; 1980 November; Tokyo, Japan. $67-78$.

$7.20 \mathrm{Hsu}$, N.N.; Breckenridge, F.R. Characterization and calibration of acoustic emission sensors. Matls. Eval. 39(1): 60-68; 1981 January.

$7.21 \mathrm{Hsu}$, N.N. Experimental determination of point-impact force-time function. Proceedings of the 4th SESA international congress on experimental mechanics; 1980 May 25-30; Boston, Massachusetts.

7.22 Hsu, N.N.; Eitzen, D.G. The inverse problem of acoustic emission explicit determination of acoustic emission source time-functions. Review of progress in quantitative nondestructive evaluation, Vol. 1. D.0. Thompson; D. E. Chimenti, eds. New York: Plenum Press; 1982. 405-412.

7.23 Proctor, T.M.,Jr. An improved piezoelectric acoustic emission transducer. J. Acoust. Soc. Am. 71(5): 1163-1168; 1982 May.

7.24 Proctor, T.M. Further development of the NBS conical transducer. Technical activities 1982 -- Office of Nondestructive Evaluation. H. T. Yolken, ed. Nat. Bur. Stand. (U.S.) NBSIR 82-2617; 1982 December. 20-24.

7.25 Proctor, T.M.,Jr. Improved piezoelectric transducers for acoustic emission signal reception. J. Acoust. Soc. Am. 68 (Supp1. 1): S68; 1980 Fall (abstract only)

7.26 Proctor, T.; Eitzen, D. NBS point displacement sensor, Appendix E in A review of advanced acoustic emission sensors. D. K. Lemon, ed. Naval Air Development Center (U.S.) NADC-81087-60; 1981 April. 11 p.

7.27 Proctor, T.M., Jr. Some details on the NBS conical transducer. J. Acoust. Emission 1(3): 173-178; 1982.

\section{Ultrasonics}

8.1 Birnbaum, G.; Eitzen, D.G. Future directions for ultrasonic NDE standards. Proceedings of the tenth world conference on nondestructive testing; 26 August 1982; Moscow, U.S.S.R. 267-272.

8.2 Birnbaum, G.; Berger, H.; Eitzen, D.G. Traceable NDE standards. Nondestruc. Test. Inform. Analysis Cen. Newsletter 9(3): 1-4; 1981 September. 
8.3 Blessing, G.V.; Elban, W.L. Aluminum matrix composite elasticity measured ultrasonically. J. Appl. Mech. 48: 965-966; 1981 December.

8. 4 Blessing, G.; Hsu, N.; Proctor, T. An ultrasonic residual stress reference sample. Technical activities 1982 -- Office of Nondestructive Evaluation. H. T. Yolken, ed. Nat. Bur. Stand. (U.S.) NBSIR 82-2617; 1982 December. 113-114.

8.5 Blessing, G.; Eitzen, D. Improved ultrasonic reference blocks. Technical activities 1982 -- Office of Nondestructive Evaluation. H. T. Yolken, ed. Nat. Bur. Stand. (U.S.) NBSIR 82-2617; 1982 December. 47-49.

8.6 Blessing, G. Ultrasonic applications to NDT and materials evaluation. Technical activities 1982 -- Office of Nondestructive Evaluation. H. T. Yolken, ed. Nat. Bur. Stand. (U.S.) NBSIR 82-2617; 1982 December. 112.

8.7 Blessing, G.V.; Elban, W.L.; Foltz, J.V. Ultrasonic characterization of aluminum matrix composites for their moduli. Berger, H.; Linzer, M., eds. Ultrasonic materials characterization - proceedings of the first international symposium on ultrasonic materials characterization; 1978 June 7-9;

Gaithersburg, Maryland. Nat. Bur. Stand. (U.S.) Spec. Pub. 596; 1980 November. 137-146.

8.8 Blessing, G.V. Ultrasonic measurements of titanium elasticity and attenuation in welds and plate. Nat. Bur. Stand. (U.S.) NBSIR 82-2500; 1982 May. 15 p.

8.9 Blessing, G.V.; Eitzen, D.G. Ultrasonic standard reference blocks--what future? Proceedings of the ASNT national conferences (Spring); 1982 March. 22-25; Boston, Massachusetts. Columbus, Ohio: American Society of Nondestructive Testing; 1982 November. 9-12.

8.10 Blessing, G.V.; Eitzen, D.G. Variables affecting ultrasonic reference block calibration. Proceedings of the ASNT national conferences (Fall); 1982 October 4-7; Pittsburgh, Pennsylvania. Columbus, Ohio; American Society of Nondestructive Testing; 1982 November. 287-291.

8.11 Eitzen, D.G.; Berger, H.; Birnbaum, G. A basis for traceable NDE measurements. Nat. Bur. Stand. (U.S.) NBSIR 80-2109; 1980 December. 14 p.

8.12 Eitzen, D.G.; Berger, H.; Birnbaum, G. A basis for traceable NDE standards. Proceedings of the DARPA/AFML review of progress in quantitative NDE. Air Force Matls. Lab. (U.S.) Tech. Report AFWAL-TR-80-4078; 1980 July. 586-589.

8.13 Eitzen, D.; Cadoff, M. NDE terms and definitions: ultrasonics. Technical activities 1982 -- Office of Nondestructive Evaluation. H. T. Yolken, ed. Nat. Bur. Stand. (U.S.) NBSIR 82-2617; 1982 December. 50.

8.14 Fick, S.; Tschiegg, C. Transfer standards for ultrasonic power measurements. Technical activities 1982 -- Office of Nondestructive Evaluation. H. T. Yolken, ed. Nat. Bur. Stand. (U.S.) NBSIR 82-2617; 1982 December. 46. 
8.15 Golan, S. Defect characterization and dimensioning of cracks in welds by the ultrasonic diffraction method. Nat. Bur. Stand. (U.S.) NBSIR 80-1983; 1980 March. 22 p.

8.16 Golan, S. Optimization of the crack tip ultrasonic diffraction technique for sizing of cracks. Matls. Eval. 39: 166-169; 1981 February.

8.17 Golan, S. Sizing of cracks with scattered ultrasonic waves. Berger, H.; Linzer, M., eds. Ultrasonic materials characterization - proceedings of the first international symposium on ultrasonic materials characterization; 1978 June 7-9; Gaithersburg, Maryland. Nat. Bur. Stand. (U.S.) Spec. Pub. 596; 1980 November. 29-36.

8.18 Golan, S.; Adler, L.; Cook, K.V.; Nanstad, R.K.; Bolland, T.K. Ultrasonic diffraction technique for characterization of fatigue cracks. J. Nondestruc. Eva1. 1(1): 11-19; 1980.

8.19 Greenspan, M. Acoustic research in the physical sciences. J. Acoust. Soc. Am. 68(1): 29-35; 1980 July.

8.20 Hsu, N.N.; Proctor, T.M., Jr•; Blessing, G.V. An analytical approach to reference samples for ultrasonic residual stress measurement. J. Test. and Eval. 10(5): 230-234; 1982 September.

8.21 Knab, L.I.; Blessing, G.V.; Clifton, J.R. Laboratory evaluation of ultrasonics for crack detection in concrete. Am. Concrete Inst. (ACI) J. Proceedings $80(1)$ : 17-27; 1983 January-February.

8.22 Nadeau, F.; Fick, S.; Rosen, M.; Horowitz, E. Magnetostrictively-driven ultrasonic device for sound velocity measurements in thin ribbons. Johns Hopkins University, Center for Materials Research Report No. CMR-NDE-3; 1981 November •

8.23 Proctor, T.M., Jr. Introduction to papers presented at the symposium on ultrasonic measurements of stress. J. Test. \& Eval. 10(5): 199-201; 1982 September.

8.24 Rosen, M.; Horowitz, E.; Fick, S.; Reno, R.C.; Mehrabian, R. An investigation of the precipitation-hardening process in aluminum alloy 2219 by means of sound wave velocity and ultrasonic attenuation. Matls. Sci. and Eng. 53: $163-177$; 1982 .

8.25 Rosen, M.; Fick, S.; Nadeau, F.; Mehrabian, R. Contactless laser generation and optical interferometric detection of ultrasonic waves. Technical activities 1982 -- Office of Nondestructive Evaluation. H. T. Yolken, ed. Nat. Bur. Stand. (U.S.) NBSIR 82-2617; 1982 December. 51-52.

8.26 Rosen, M.; Horowitz, E.; Fick, S.; Mehrabian, R. Dynamic monitoring of the precipitation hardening process in 2219 aluminum alloy by means of sound velocity and attenuation measurements. Proceedings of the ultrasonic symposium; 1981 October; Chicago, Illinois. 945-947. 
8.27 Rosen, M.; Fick, S.; Horowitz, E. An ultrasonic investigation of precipitation hardening phenomena in 2219 aluminum alloy. Johns Hopkins University, Center for Materials Research Report No. CMR-NDE-1; 1981 March. $62 \mathrm{p}$.

8.28 Rosen, M.; Fick, S.; Friant, C.L.; Horowitz, E. Nondestructive characterization of the precipitation hardness process in aluminum alloys. Johns Hopkins University, Center for Materials Research Report No. CMR-NDE-2; 1981 September. 49 p.

8.29 Rosen, M.; Fick, S.; Horowitz, E. Correlation of ultrasonic data with hardness after aging 2024 aluminum alloy under T4, T351, and T851 conditions. Johns Hopkins University, Center for Materials Research Report No. CMR-NDE-4; 1982 February. 24 p.

8.30 Rosen, M.; Horowitz, E.; Schwartzendruber, L.; Fick, S.; Mehrabian, R. The aging process in aluminum alloy 2024 studied by means of eddy currents. Matls. Sci. and Eng. 53: 191-198; 1982.

8.31 Tschiegg, C.E.; Greenspan, M.; Eitzen, D.G. Ultrasonic continuous-wave beam-power measurements; international intercomparison. J. Res. NBS 88(2). (to be published in Spring 1983)

9. Miscellaneous

9.1 Gilsinn, D.E. A high order generalized method of averaging. SIAM J. App1. Math. 42(1): 113-134; 1982 February.

9.2 Marx, E. TNF/S C $3 / D-T A C N E T$, a model of the Army's tactical communications networks in Europe. Harry Diamond Labs. (U.S.) Report HDL-TR-1913; 1980 January.

9.3 Noon, T.V.; Marx, E. CONDUCT, a simulation model of the Armies' command, control, and communications $\left(C^{3}\right)$ process. Harry Diamond Labs. (U.S.) Report HDL-TR-1974; 1981 November.

9.4 Register, D.; Trajmar, S.; Jensen, S.; Poe, R. Photon polarization dependence of superelastic electron scattering by laser-excited barium. Coherence and correlation in atomic collisions. H. Kleinpopper; J. F. Williams, eds. New York, New York: Plenum Press; 1980. 641-649.

9.5 Robinson, D.C. Assessment of the kickback energy potential for chain saws. Nat. Bur. Stand. (U.S.) NRSIR 81-2193; 1981 January. 49 p.

9.6 Robinson, D.; Federman, C. Evaluation of chain saw kickback motion using an optoelectric measurement system. Nat. Bur. Stand. (U.S.) NBSIR 82-2559; 1982 August. 63 p. 
Only those authors who are or have been members of the Mechanical Production Metrology Division are included below:

\section{Author}

Blessing, G.V.

Breckenridge, F.R.

Burnett, E.D.

Cadoff, M.

Corley, D.M.

Corliss, E.L.R.

Donavan, P.

Eitzen, D.G.

Federman, C.

Fick, S.E.

Flynn, D.R.

Gilsinn, D.

Golan, S.

Greenspan, M.

Hartman, A.W.

Hembree, G. G.

Hsu, N.N.

Jenkins, W.D.
Paper Numbers

$8.3,8.4,8.5,8.6,8.7,8.8,8.9,8.10$, $8.20,8.21$

$7.5,7.6,7.7,7.11,7.12,7.14,7.15$, $7.16,7.20$

$5.4,5.5,5.6,5.7,5.8,5.17$

$5.23,8.13$

5.23

$5.8,5.9,5.10$

5.11

$7.2,7.3,7.4,7.9,7.10,7.11,7.12$, $7.13,7.14,7.15,7.16,7.18,7.19$, $7.22,7.26,8.1,8.2,8.5,8.9,8.10$, $8.11,8.12,8.13,8.31$

9.6

$7.8,8.14,8.22,8.24,8.25,8.26,8.27$, $8.28,8.29,8.30$

$5.3,5.11,5.12,5.13,5.21,5.22,5.23$, 5.24

$2.7,9.1$

$8.15,8.16,8.17,8.18$

$5.14,7.7,7.17,7.18,8.19,8.31$

$1.1,1.7,1.15$

$1.2,1.3,1.5$

$7.11,7.12,7.14,7.15,7.16,7.19$,

$7.20,7.21,7.22,8.4,8.20$

$1.8,1.9$ 
Author

Jensen, S.W.

Lettieri, T.R.

Lieberman, A.G.

Marchiando, J.F.

Marx, E.

Maystre, D.

McLay, M.

Mitchell, R.A.

Nedzelnitsky, V.

Payne, B. F.

Pontius, P.E.

Proctor, ז̃.M., Jr.

Robinson, D.C.

Scire, F。E.

Serhyn, M.R.

Swyt, D.A.

Teague, E.C.

Trahan, C.Y.

Tschiegg, C.E.

Voorhees, C.R.

Vorburger, T.V.

Young, R.D.

\section{Paper Numbers}

$1.2,1.3,1.4,1.5,1.6,1.13,1.14$, $1.15,2.6,2.10$

$1.8,1.9,1.15$

$3.1,3.2,3.3,3.4,3.5,3.6,3.7,3.8$

$1.2,1.3,1.5,3.8$

$1.10,3.9,3.10,3.11,3.12,9.2,9.3$

$2.11,3.9$

2.7

$4.1,4.3,4.4$

$5.8,5.15,5.16,5.17,5.18,5.19,5.20$

$6.1,6.2,6.3,6.7$

$4.3,4.4,4.5$

$7.11,7.14,7.15,7.23,7.24,7.25$,

$7.26,7.27,8.4,8.23$

$9.5,9.6$

$2.3,2.4,2.5,2.6,2.7,2.9,2.10$, $2.14,2.16$

$6.4,6.5,6.6,6.7,6.8$

$1.5,1.6,1.8 .1 .9,1.11,1.12,1.13$, $1.14,1.15,1.16$

$2.3,2.4,2.5,2.6,2.7,2.8,2.9,2.10$, $2.11,2.14,2.15,2.16,2.17$

$2.6,2.7,2.12$

$7.17,8.14,8.31$

5.12

$2.1,2.2,2.3,2.4,2.6,2.7,2.8,2.9$, $2.11,2.13,2.14,2.15,2.16,2.17$.

$1.7,2.3,2.4,2.17$ 
NBS.114A (REV. 2.80)

U.S. DEPT. OF COMM.

BIBLIOGRAPHIC DATA

SHEET (See instructions)

1. PUBLICATION OR

REPORT NO.

NBSIR 83-2699

May 1983

4. TITLE AND SUBTITLE

Publications in 1980-1982 of the Mechanical Production Metrology Division

5. AUTHOR(S)

Marilyn A. Cadoff

6. PERFORMING ORGANIZATION (If joint or other than NBS, see in structions)

NATIONAL BUREAU OF STANDARDS

DEPARTMENT OF COMMERCE

WASHINGTON, D.C. 20234

9. SPONSORING ORGANIZATION NAME AND COMPLETE ADDRESS (Street, City, State, ZIP)

7. ContracuGrant No.

8. Type of Report \& Period Covered

10. SUPPLEMENTARY NOTES

[ Document describes a computer program; SF-185, FIPS Software Summary, is attached.

11. ABSTRACT (A 200-word or less factual summary of most significant information. If tocument includes a significant bibliography or literature survey, mention it here)

This bibliography lists the publications of the personnel of the Mechanical Production Metrology Division from January 1980 through December 1982. Included in it are publications for which one or more authors were in the Division during this period, as well as a few publications that were written in support of Division programs, even though none of the authors were members of the

Division.

12. KEY WORDS (Six to twelve entries; alphabetical order; capitalize only proper names; and separate key words by semicolons) Acoustic emission; acoustics; force; mass; micrometrology; surface topography; ultrasonics, vibration; wave optics.

13. AVAILABILITY

[X] Unlimited

$\square$ For Official Distribution. Do Not Release to NTIS

$\square$ Order From Superintendent of Documents, U.S. Government Printing Office, Washington, D.C. 20402.

[X] Order From National Technical Information Service (NTIS), Springfield, VA. 22161

14. NO. OF

PRINTED PAGES

17

15. Price

$\$ 7.00$ 


\section{.}



